Jurnal Riset Manajemen Sains Indonesia (JRMSI) | Vol 12, No. 2, 2021 e-ISSN: 2301-8313

http://doi.org/10.21009/JRMSI

DOI: doi.org/10.21009/JRMSI.009.1.09

\title{
Keputusan Konsumen Membeli Sayur Menggunakan Aplikasi Online : Apakah WoM dan Kualitas Produk Mempengaruhi?
}

\author{
Vanya Vydiamanta \\ Fakultas Ekonomi, Universitas Negeri Jakarta, Indonesia \\ Email: vanyavydiamanta@unj.ac.id \\ Usep Suhud, M.Si., Ph.D. \\ Fakultas Ekonomi, Universitas Negeri Jakarta, Indonesia \\ Email: usuhud@unj.ac.id \\ Ika Febrilia, SE, M.M. \\ Fakultas Ekonomi, Universitas Negeri Jakarta, Indonesia \\ Email: ikafebrilia@unj.ac.id
}

\begin{abstract}
ABSTRAK
Penelitian ini menganalisis faktor-faktor yang mempengaruhi keputusan konsumen untuk membeli sayuran melalui aplikasi online. Beberapa variabel yang digunakan untuk mengukur keputusan pembelian adalah gaya hidup, harga, kualitas produk, word of mouth, dan brand image. Dalam penelitian ini, metode yang digunakan adalah metode survei. Populasi dalam penelitian ini adalah seluruh masyarakat yang berada di wilayah Jabodetabek dan mengetahui tentang jasa jual beli sayur online. Dari hasil kuesioner, diperoleh sebanyak 256 responden. Dari seluruh responden terdapat 241 data yang dapat diterima sebagai sampel. Karakteristik sampel penelitian ini antara lain masyarakat di wilayah Jabodetabek, masyarakat yang mengetahui tentang jasa jual beli sayur online, masyarakat yang pernah melakukan minimal satu kali pembelian di jasa jual beli sayur online. ada 5 hipotesis; gaya hidup berpengaruh signifikan terhadap keputusan pembelian, harga berpengaruh signifikan terhadap citra merek, kualitas produk berpengaruh signifikan terhadap merek, word of mouth berpengaruh signifikan terhadap keputusan pembelian, dan citra merek berpengaruh signifikan pada keputusan pembelian. ada 5 hasil dari penelitian ini, diantaranya; variabel gaya hidup tidak berpengaruh terhadap keputusan pembelian, variabel harga berpengaruh terhadap citra merek, variabel kualitas produk berpengaruh terhadap citra merek, variabel word of mouth tidak berpengaruh terhadap keputusan pembelian, dan variabel citra merek merek berpengaruh terhadap keputusan pembelian.
\end{abstract}

Kata Kunci: Gaya Hidup, Harga, Kualitas Produk, Word of Mouth, Citra Merek, Keputusan Pembelian 
Jurnal Riset Manajemen Sains Indonesia (JRMSI) | Vol 12, No. 2, 2021 e-ISSN: 2301-8313 http://doi.org/10.21009/JRMSI

\section{PENDAHULUAN}

Saat ini perkembangan teknologi internet terjadi sangat cepat dan berpengaruh di segala aspek kehidupan (Foster \& Johansyah, 2019). Kegiatan yang telah didigitalkan juga tidak terbatas pada komunikasi (Esarey, 2011), tetapi juga kegiatan ekonomi (Tambunan \& Anwar, 2019), sosial (Aji, 2016), politik (Saud et al., 2020), dan pendidikan (Akbar, 2016). \& Anggraeni, 2017). Pengguna smartphone, internet, dan media sosial memiliki angka yang tinggi dibandingkan dengan jumlah penduduk pada tahun 2020. Dari pernyataan tersebut juga dapat disimpulkan bahwa mayoritas masyarakat Indonesia sadar akan pentingnya teknologi dan digitalisasi dalam kehidupan (Pilliang, 2012). Meningkatnya kesadaran masyarakat akan teknologi memberikan pengaruh dalam berbagai hal. Salah satu hal yang terpengaruh adalah proses jual beli. Perkembangan teknologi membuat proses jual beli juga semakin berkembang. Salah satu perkembangannya dapat dilihat dari fenomena munculnya berbagai e-commerce di Indonesia. Pembeli dapat lebih mudah menjangkau penjual dengan menggunakan berbagai platform. Barang yang ditawarkan juga sangat bervariasi sehingga semakin diminati pembeli. Menurut data statistik, perkembangan transaksi e-commerce di Indonesia setiap tahun selalu meningkat. Pernyataan ini juga dapat diartikan bahwa setiap tahun pengguna e-commerce juga semakin meningkat.

Salah satu bisnis yang terus berkembang di masa pandemi Covid-19 adalah bisnis retail. Terutama yang melayani kebutuhan sehari-hari seperti produk segar seperti sayuran dan buahbuahan. Kebijakan Pembatasan Sosial Berskala Besar (PSBB) membuat sebagian besar masyarakat membeli produk segar tersebut melalui jalur online. Terutama melalui platform penjualan produk sayur dan buah. Fenomena peningkatan penggunaan e-commerce juga terjadi pada jasa jual beli sayur secara online (Djumena, 2020). Adanya fenomena tersebut dalam perilaku konsumen menjadi dasar penelitian ini. Pada fenomena tersebut peneliti ingin menganalisis faktor-faktor yang mempengaruhi keputusan konsumen untuk melakukan pembelian pada jasa jual beli sayuran online. Beberapa faktor tersebut antara lain harga, kualitas produk, gaya hidup, word of mouth, dan citra produk sebagai variabel intervening.

\section{TELAAH PUSTAKA}

\section{Keputusan Pembelian}

Keputusan adalah pilihan sadar yang dibuat oleh manusia untuk menentukan antara dua atau lebih alternatif. Konsumen membuat banyak pilihan setiap hari dan tahap ketika konsumen membuat pilihan dari produk atau jasa alternatif yang tersedia disebut proses pengambilan 
Jurnal Riset Manajemen Sains Indonesia (JRMSI) | Vol 12, No. 2, 2021 e-ISSN: 2301-8313 http://doi.org/10.21009/JRMSI

keputusan konsumen atau proses keputusan pembelian konsumen (Amanah et al., 2018). Ada lima tahapan dalam keputusan pembelian, termasuk pengenalan masalah, pencarian informasi, evaluasi alternatif, keputusan pembelian, dan perilaku pasca pembelian (Kotler \& Armstrong, 2008). Keputusan pembelian meliputi beberapa pilihan yang terbentuk atas keinginan konsumen untuk memenuhi kebutuhannya. Keputusan pembelian konsumen secara spesifik mengacu pada aktivitas yang dilakukan konsumen ketika memutuskan apa yang akan dibeli dan kapan melakukan pembelian yang sebenarnya (Peter \& Olson, 2005). Ketika konsumen telah memilih suatu produk untuk dibeli, maka konsumen secara langsung telah melaksanakan keputusan pembelian melalui pembelian yang sebenarnya.Sebagai konsumen, pengambilan keputusan untuk membeli suatu produk mungkin memerlukan beberapa pertimbangan, seperti di mana konsumen harus melakukan pembelian, berapa banyak uang yang harus dikeluarkan, dan waktu yang dibutuhkan untuk melakukan suatu pembelian (Engel \& Blackwell, 2001). Beberapa indikator yang dapat menentukan faktor-faktor yang mempengaruhi keputusan pembelian adalah budaya, sosial, individu, psikologis, dan bauran pemasaran (Kotler, 2005). Dengan berbagai teori yang telah dibahas sebelumnya, dapat disimpulkan bahwa keputusan pembelian merupakan pilihan yang dilakukan oleh konsumen dalam menentukan barang atau jasa mana yang akan dibeli dengan berbagai pertimbangan untuk memenuhi kebutuhan atau keinginannya.

\section{Harga}

Harga adalah suatu nilai tukar yang dapat berupa uang atau barang lain dengan maksud untuk memperoleh manfaat dari suatu barang atau jasa guna memenuhi kebutuhan dan keinginan konsumen akan suatu produk. Harga adalah satu-satunya elemen bauran pemasaran yang memberikan pendapatan bagi produsen. Persepsi harga memiliki pengaruh yang besar terhadap keputusan pembelian. Oleh karena itu, keputusan untuk menentukan harga bukanlah hal yang mudah. Persepsi harga menjelaskan informasi tentang produk dan mengakomodasi makna produk bagi konsumen (Kotler \& Keller, 2016). Di satu sisi, harga yang terlalu tinggi dapat menyebabkan peningkatan keuntungan jangka pendek, tetapi akan sangat sulit untuk menjangkau konsumen dan bersaing dengan pesaing (Huber et al., 2007). Sebaliknya, jika harga yang ditawarkan terlalu murah, pangsa pasar akan meningkat tetapi margin kontribusi dan laba bersih akan menurun.

Selain itu, beberapa konsumen mungkin juga menerima barang atau jasa dengan kualitas yang tidak memadai (Boksberger \& Melsen, 2011). Secara bersamaan, konsumen juga 
Jurnal Riset Manajemen Sains Indonesia (JRMSI) | Vol 12, No. 2, 2021 e-ISSN: 2301-8313 http://doi.org/10.21009/JRMSI

menjadi sangat rasional ketika menimbang antara kegunaan yang diharapkan konsumen setelah membayar harga tertentu untuk barang atau jasa tertentu (Al-Mahmud \& Rahman, 2014). Dengan berbagai teori yang telah dibahas sebelumnya, dapat disimpulkan bahwa harga adalah suatu satuan pertukaran yang digunakan oleh masyarakat sebagai tolak ukur untuk memperoleh manfaat dari barang atau jasa yang dibutuhkan atau diinginkan.Product

\section{Quality}

Kualitas adalah tingkat baik buruknya kualitas, kadar atau derajat sesuatu. Dalam hal ini yang dimaksud adalah produk, baik barang maupun jasa. Jadi, kualitas dapat diartikan sebagai tingkat kesesuaian antara spesifikasi suatu produk dengan kebutuhan dan harapan konsumen. Produk dapat dikatakan berkualitas tinggi apabila produk tersebut mampu memenuhi harapan pelanggan (Habibah \& Sumiati, 2016).

Kualitas produk adalah kemampuan suatu produk untuk mengekspresikan kegunaan produk melalui daya tahan, keandalan, akurasi, kemudahan, pengoperasian, dan perbaikan. Ketika produk telah melebihi kegunaannya, produk tersebut dapat dinyatakan memenuhi harapan pelanggan (Kotler \& Armstrong, 2008). Produk pada dasarnya memiliki beberapa tingkatan mutu, antara lain mutu rendah atau mutu rendah, mutu sedang atau mutu rata-rata sedang, mutu baik atau mutu baik, dan mutu prima (Kotler \& Armstrong, 2008).

Kualitas produk umumnya dapat diukur dengan menggunakan atribut-atribut tertentu secara objektif. Namun dari segi kualitas pemasaran hanya dapat diukur secara objektif jika telah melalui persepsi konsumen terhadap kualitas suatu produk. Kualitas produk merupakan strategi potensial untuk mengalahkan pesaing dan meningkatkan keputusan pembelian (Kotler \& Armstrong, 2008). Jadi, perusahaan dengan barang berkualitas baik akan tumbuh lebih baik dari perusahaan lain.

Dengan berbagai teori yang telah dibahas sebelumnya, dapat disimpulkan bahwa kualitas produk merupakan ukuran baik buruknya suatu produk atau jasa yang ditentukan oleh pendapat masing-masing konsumen berdasarkan pengalaman dan berbagai faktor pendukung lainnya.

\section{Life Style}

Gaya hidup adalah cara seseorang menjalani hidupnya. Ini mencerminkan pekerjaan, perilaku sosial, dan perilaku individu. Bentuk-bentuk gaya hidup pada individu dan kelompok meliputi aktivitas, perilaku, minat, opini, nilai, dan alokasi pendapatan. Gaya hidup juga bisa menjadi konsep untuk menganalisis konsumen (Maney, 2014). Konsep ini, secara langsung 
Jurnal Riset Manajemen Sains Indonesia (JRMSI) | Vol 12, No. 2, 2021 e-ISSN: 2301-8313 http://doi.org/10.21009/JRMSI

memperluas sisi pemasaran suatu produk. Semakin baik suatu perusahaan mengenali konsumen, maka semakin baik pula komunikasi dan pemasaran yang dapat diterapkan. Gaya hidup mendapatkan momentum untuk lebih memahami nilai menjadi alat dalam melakukan pemasaran di seluruh dunia (Chu \& Lee, 2007). Ada banyak penelitian yang dilakukan untuk mengetahui pengaruh antara gaya hidup dan perilaku konsumen.

Segmentasi teknik gaya hidup telah menjadi hal yang lebih berharga untuk strategi periklanan. Gaya hidup merupakan perwujudan dari konsep diri dan pengembangan dari kombinasi pengalaman, karakteristik, dan lingkungan (Maney, 2014). Gaya hidup juga merupakan sesuatu yang mempengaruhi individu karena kombinasi faktor lingkungan, budaya, dan sosial (Maney, 2014). Dengan berbagai teori yang telah dibahas sebelumnya, dapat disimpulkan bahwa gaya hidup adalah suatu kegiatan, perilaku, atau kebiasaan yang dipilih dan dijalani oleh seorang individu sehingga dapat mencerminkan bagaimana seorang individu menjalani kehidupannya sehari-hari..

\section{Word of mouth}

Komunikasi dari mulut ke mulut atau word of mouth communication adalah proses komunikasi berupa pemberian rekomendasi tentang suatu produk atau jasa antar individu atau kelompok dengan tujuan memberikan informasi pribadi (Kotler \& Armstrong, 2008). WOM merupakan salah satu jenis komunikasi informal yang dilakukan secara interpersonal. WOM biasanya berisi informasi pribadi yang dirasakan oleh konsumen tentang suatu perusahaan, merek, atau produk. Ketika konsumen ingin melakukan pembelian produk baru, konsumen biasanya menerima rekomendasi melalui WOM. Konsumen menggunakan WOM karena lebih cepat, lebih dapat diandalkan, dan berisi informasi yang cukup efektif (Zarei \& Kazemi, 2014). WOM dapat diartikan sebagai proses dimana konsumen dapat berbagi informasi dan opini yang mendorong calon pembeli untuk membeli atau tidak membeli produk, merek dan jasa tertentu (Zarei \& Kazemi, 2014). WOM dapat memuat pemikiran dasar seorang konsumen tentang nilai produk, jasa, toko, jasa, dan perusahaan yang disebarluaskan melalui komunikasi.

Informasi WOM dipengaruhi oleh beberapa faktor. Faktor-faktor tersebut dapat dibagi menjadi dua, yaitu faktor emosional yang merupakan faktor penyebab keinginan, kebutuhan, dan harapan yang disimulasikan oleh peristiwa yang menimbulkan kecemasan atau kecemasan dan faktor kognitif yang merupakan faktor yang timbul dari ketidakpastian dan ketidakmampuan untuk memprediksi sesuatu (Allshop dkk., 2007). Selain kedua faktor tersebut, ada juga dua faktor lainnya, yaitu faktor opini pemimpin dan ikatan sosial (Huges, 
Jurnal Riset Manajemen Sains Indonesia (JRMSI) | Vol 12, No. 2, 2021 e-ISSN: 2301-8313 http://doi.org/10.21009/JRMSI

2007). Oleh karena itu, dapat disimpulkan bahwa promosi dari mulut ke mulut adalah suatu proses dimana informasi tentang suatu produk atau jasa disampaikan dari satu individu ke individu lain dengan tujuan untuk memberikan referensi tentang produk atau jasa yang bersangkutan..

\section{Brand Image}

Merek adalah suatu produk, jasa, atau konsep yang dikenal di masyarakat dan sebagai pembeda antara satu produk dengan produk lainnya. Merek juga sering dijadikan sebagai konsep untuk menyampaikan produk ke pasar. Proses branding adalah proses menciptakan dan menyebarluaskan merek dan nama produk. Branding dapat digunakan untuk seluruh identitas perusahaan serta produk individu. Dari sekian banyak strategi pemasaran yang ada, salah satu strategi yang paling ampuh adalah proses branding dan penciptaan citra merek untuk menghilangkan penilaian yang berlebihan terhadap suatu produk atau merek (Yasmin, 2017). Kekuatan citra merek merupakan sesuatu yang dapat menjadi jembatan antara konsumen dan produsen (Park et al., 2010). Konsumen pada dasarnya melakukan proses seleksi sebelum akhirnya membeli produk yang sesuai dengan kebutuhan dan keinginan konsumen. Pada tahap ini, ekuitas merek sangat berpengaruh terhadap proses pemilihan produk oleh konsumen. Ketika konsumen dapat merasakan kepercayaan terhadap suatu merek, otomatis konsumen akan semakin konsisten dengan merek tersebut dan berdampak baik terhadap keputusan pembelian dan pendapatan perusahaan. Dengan berbagai teori yang telah dibahas sebelumnya, dapat disimpulkan bahwa citra merek merupakan kesan yang membuat perbedaan antara satu produk dengan produk lainnya dan diperoleh dari masyarakat melalui hasil opini terhadap suatu merek berdasarkan berbagai faktor.. 
Jurnal Riset Manajemen Sains Indonesia (JRMSI) | Vol 12, No. 2, 2021 e-ISSN: 2301-8313 http://doi.org/10.21009/JRMSI

\section{KEEANGKA TEORITIK}

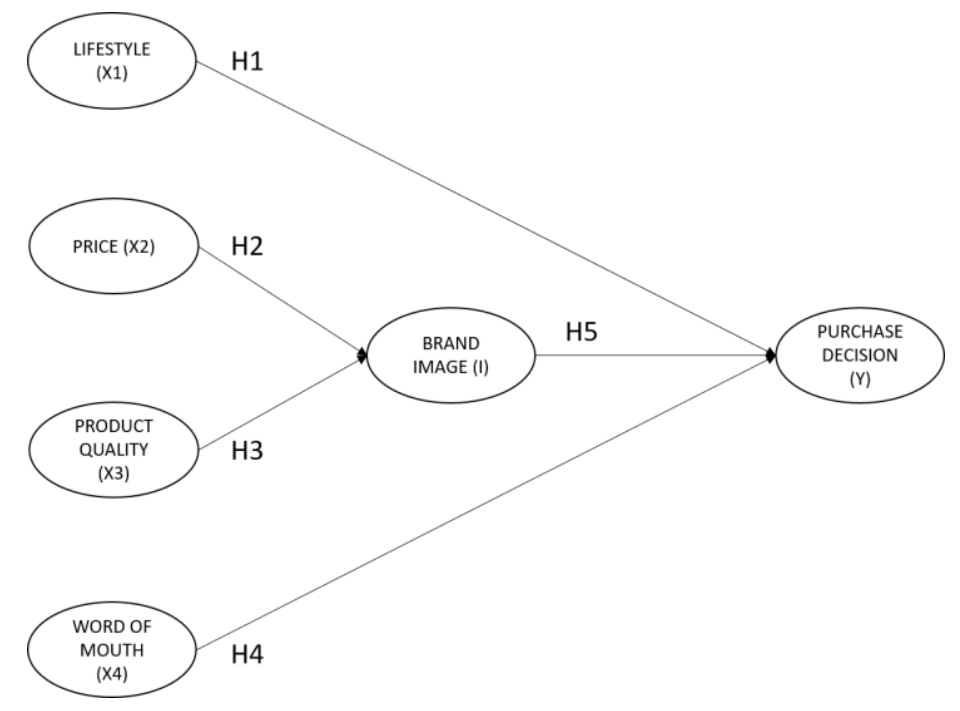

Gambar 1. Model Penelitian

Sumber: Data diolah peneliti (2021

\section{HIPOTESIS}

Hipotesis yang diajukan oleh penelitian ini antara lain:

H1: Gaya hidup akan berpengaruh signifikan terhadap keputusan pembelian pada jasa jual beli sayur online.

H2: Harga akan berpengaruh signifikan terhadap citra merek pada jasa jual beli sayuran online.

H3: Kualitas produk akan berpengaruh signifikan terhadap citra merek pada jasa jual beli sayuran online.

H4: Word of mouth akan berpengaruh signifikan terhadap keputusan pembelian jasa jual beli sayuran online.

H5: Brand image akan berpengaruh signifikan terhadap keputusan pembelian pada jasa jual beli sayur online.

\section{METODE PENELITIAN}

\section{Responden}

Sampel dalam penelitian ini didapat dari hasil pendistribusian yang dilakukan peneliti secara online melalui google form. Dari hasil kuesioner, diperoleh sebanyak 256 responden. Dari seluruh responden terdapat 241 data yang dapat diterima sebagai sampel. Responden yang diterima adalah responden yang berdomisili di Jabodetabek dalam satu tahun terakhir, 
Jurnal Riset Manajemen Sains Indonesia (JRMSI) | Vol 12, No. 2, 2021 e-ISSN: 2301-8313 http://doi.org/10.21009/JRMSI

mengetahui tentang jasa jual beli sayur online, dan pernah melakukan minimal satu kali pembelian dengan jasa jual beli sayur online.

\section{Pengukuran}

Dalam penelitian ini, skala pengukuran yang digunakan peneliti adalah skala Likert. Penelitian yang dilakukan peneliti menggunakan skala genap atau skala penilaian enam poin yang terdiri dari "sangat tidak setuju" hingga "sangat setuju". Dalam penelitian ini, jenis data yang digunakan adalah data primer. Teknik pengumpulan data yang peneliti pilih adalah kuesioner. Kuesioner, yang peneliti kelola, terdiri dari tiga bagian. Bagian pertama adalah screening test, digunakan untuk menyeleksi apakah responden sesuai dengan kriteria peneliti. Bagian kedua adalah pemikiran responden tentang enam variabel yang akan diteliti: gaya hidup, harga, kualitas produk, dari mulut ke mulut, citra merek, dan keputusan pembelian. Bagian ketiga adalah informasi tentang identitas responden yang memuat jenis kelamin, umur, status pekerjaan, jenis pekerjaan, penghasilan, dan domisili..

\section{Analysis}

Peneliti menggunakan software Structural Equation Model (SEM) untuk memilih program. Peneliti menggunakan AMOS versi 26, untuk mengolah data dari kuesioner yang diperoleh dan SPSS versi 26 untuk menguji validitas dan reliabilitas. Dalam penelitian ini peneliti menggunakan beberapa uji analisis data, yaitu: 1). Analisis deskriptif digunakan untuk memberikan gambaran atau ringkasan data. 2). Uji validitas digunakan untuk mengukur validitas atau ketidakabsahan data yang diambil dari kuesioner dalam mengukur validitas penelitian ini menggunakan Exploratory Factor Analysis (EFA) dan Confirmatory Factor Analysis (CFA). 3). Uji reliabilitas adalah uji reliabilitas yang berupaya menilai cara penggunaan alat ukur yang aman. Untuk menguji reliabilitas menggunakan rumus alpha cronbach. 4). Analisis dalam model fit test melalui tinjauan berbagai parameter goodness of fitness (D’Agostino, 2017).

Table 1. Goodness of Fit Index

\begin{tabular}{lll}
\hline & $\begin{array}{l}\text { The goodness of Fit } \\
\text { Index }\end{array}$ & Cut-off Value \\
\hline 1 & X2, Chi-Square & Smaller is better \\
2 & Probability & $\geq 0.05$ \\
3 & GFI & $\geq 0.90$ \\
4 & RMSEA & $\leq 0.08$ \\
5 & AGFI & $\geq 0.90$
\end{tabular}


Jurnal Riset Manajemen Sains Indonesia (JRMSI) | Vol 12, No. 2, 2021 e-ISSN: 2301-8313 http://doi.org/10.21009/JRMSI

\begin{tabular}{lll}
6 & TLI & $\geq 0.90$ \\
7 & NFI & $\geq 0.90$ \\
\hline
\end{tabular}

Sumber: D’Agostino, (2017)

\section{KESIMPULAN DAN SARAN}

Sampel dalam penelitian ini didapat dari hasil pendistribusian yang dilakukan peneliti secara online melalui google form. Dari hasil kuesioner, diperoleh sebanyak 256 responden. Dari seluruh responden terdapat 241 data yang dapat diterima sebagai sampel. Responden yang diterima adalah responden yang berdomisili di Jabodetabek dalam satu tahun terakhir, mengetahui tentang jasa jual beli sayur online, dan pernah melakukan minimal satu kali pembelian dengan jasa jual beli sayur online.

\section{Analisis Deskriptif}

Analisis deskriptif variabel harga (x1) memiliki hasil persentase rata-rata sebesar $1,00 \%$ pada poin sangat tidak setuju, 1,66\% pada poin tidak setuju, 6,89\% pada poin sedikit tidak setuju, $26,64 \%$ pada poin sedikit setuju, 40,50\% pada poin setuju, dan $23,32 \%$ pada poin sangat setuju. Dari keseluruhan hasil jawaban responden, dapat disimpulkan bahwa responden memiliki kecenderungan untuk memberikan jawaban yang positif pada kuesioner variabel harga.

Analisis deskriptif variabel Word of Mouth (x2) memiliki persentase rata-rata sebesar $1,83 \%$ pada poin sangat tidak setuju, 2,24\% pada poin tidak setuju, 10,21\% pada poin sedikit tidak setuju, 25,39\% sedikit setuju, 35,52\% setuju, dan 24,81\% sangat setuju . Dari keseluruhan hasil jawaban responden, dapat disimpulkan bahwa responden memiliki kecenderungan untuk memberikan jawaban yang positif pada kuesioner variabel Word of Mouth.

Analisis deskriptif variabel kualitas produk (x3) memiliki hasil persentase rata-rata sebesar $0,91 \%$ pada poin sangat tidak setuju, $0,83 \%$ pada poin tidak setuju, $6,39 \%$ pada poin sedikit tidak setuju, 26,06\% pada poin sedikit setuju, 40,41\% setuju, dan 25,39\% sangat setuju. Dari keseluruhan hasil jawaban responden dapat disimpulkan bahwa responden memiliki kecenderungan memberikan jawaban positif pada kuesioner variabel kualitas produk.

Analisis deskriptif variabel gaya hidup (x5) memiliki persentase rata-rata sebesar $4,32 \%$ pada poin sangat tidak setuju, 2,66\% pada poin tidak setuju, 9,63\% pada poin sedikit tidak setuju, $23,82 \%$ pada poin sedikit setuju, 35,35\% setuju, dan $24,23 \%$ sangat setuju. Dari 
Jurnal Riset Manajemen Sains Indonesia (JRMSI) | Vol 12, No. 2, 2021 e-ISSN: 2301-8313 http://doi.org/10.21009/JRMSI

keseluruhan hasil jawaban responden, dapat disimpulkan bahwa responden memiliki kecenderungan memberikan jawaban positif pada kuesioner variabel gaya hidup.

Analisis deskriptif variabel citra merek (x4) memiliki hasil persentase rata-rata 0,58\% pada poin sangat tidak setuju, 1,24\% pada poin tidak setuju, 5,31\% pada poin agak tidak setuju, 25,64\% pada poin sedikit setuju, 40,33\% setuju, dan 26,89\% sangat setuju. Dari keseluruhan hasil jawaban responden, dapat disimpulkan bahwa responden memiliki kecenderungan untuk memberikan jawaban yang positif pada kuesioner variabel citra merek.

Analisis deskriptif variabel keputusan pembelian (Y) memiliki hasil persentase ratarata $0,58 \%$ pada poin sangat tidak setuju, $1,08 \%$ pada poin tidak setuju, $9,13 \%$ pada poin agak tidak setuju, $22,41 \%$ pada poin sedikit setuju, $42,32 \%$ setuju, dan $24,48 \%$ sangat setuju. Dari keseluruhan hasil jawaban responden, dapat disimpulkan bahwa responden memiliki kecenderungan untuk memberikan jawaban positif dalam kuesioner variabel keputusan pembelian.

\section{Analisis Faktor Eksplorasi}

Berikut adalah hasil uji analisis faktor konfirmatori untuk masing-masing variabel yang diuji:

Table 2. Exploratory Factor Analysis

\begin{tabular}{|c|c|c|c|c|}
\hline variable & Item & Statement & $\begin{array}{c}\text { Factor } \\
\text { Loadings }\end{array}$ & $\begin{array}{c}\text { Cronbach's } \\
\text { Alpha }\end{array}$ \\
\hline \multirow{4}{*}{ Price } & H1 & $\begin{array}{l}\text { I can afford the products that are } \\
\text { available in online vegetable buying and } \\
\text { selling services }\end{array}$ & 0,657 & \\
\hline & $\mathrm{H} 2$ & $\begin{array}{l}\text { I always buy online vegetable buying and } \\
\text { selling service products because they are } \\
\text { cheaper }\end{array}$ & 0,660 & \\
\hline & H3 & $\begin{array}{l}\text { The prices offered by the online } \\
\text { vegetable buying and selling service are } \\
\text { in accordance with the quality of the } \\
\text { products and services offered. }\end{array}$ & 0,661 & 0,730 \\
\hline & $\mathrm{H} 4$ & $\begin{array}{l}\text { The prices offered by online vegetable } \\
\text { buying and selling services are always in } \\
\text { accordance with the size. }\end{array}$ & 0,710 & \\
\hline
\end{tabular}


selling service because the price was

stable.

W1 I mentioned to my relatives that the

online vegetable buying and selling service is very useful because it has a high usability value

W2 I asked my relatives to buy products from the online vegetable trading service that I used

Word of

Mouth

W3 I provide information to my relatives to use the online vegetable buying and selling service products that I use

W4 I got the information on online vegetable buying and selling service products that I needed from my relatives

W5 I got good quality online vegetable buying and selling service product references from my relatives

K1 The products that the online vegetable buying and selling service offered me were still new and fresh.

K2 Eco-friendly online vegetable buying and selling service product packaging.

K3 The size of the online vegetable buying 0,663

Product quality

K4 The quality of online vegetable buying and selling service products is always the same in every purchase

K5 I always receive products from online vegetable trading services in good condition.

G1 I ordered an online vegetable buying and 0,859

Life style selling service product to make it look different from others. 
G2 I am happy to order online vegetable buying and selling service products because they are more up-to-date.

G3 I like to order online vegetable buying and selling service products because they are healthier

G4 I ordered an online vegetable buying and selling service product for a certain moment.

G5 I ordered an online vegetable shopping service product to try something new

C1 Online vegetable buying and selling service is known as an innovative company.

C2 The online vegetable buying and selling service is famous for its modern brand.

C3 Online vegetable buying and selling 0,706

Brand

image services have always had a positive impression on me.

C4 I have always believed in the online vegetable trading service product application system.

C5 The products provided by the famous online vegetable buying and selling service are always of high quality

KP1 I intend to buy vegetable from online trading service after seeing the application.

KP2 I buy online vegetable trading service products for a certain period (weekly,

Purchase monthly, yearly)

decision

KP3 I bought online vegetable buying and selling service products because these products are sold online.

KP4 I bought online vegetable buying and selling service products because I need these products for my daily activities 
Jurnal Riset Manajemen Sains Indonesia (JRMSI) | Vol 12, No. 2, 2021 e-ISSN: 2301-8313 http://doi.org/10.21009/JRMSI

$$
\begin{array}{ll}
\text { KP5 I bought an online vegetable buying and } \quad 0,630 \\
\text { selling service product because there was } \\
\text { a product I wanted }
\end{array}
$$

\section{Sumber : Data diolah peneliti}

Berdasarkan tabel di atas, tidak ada indikator yang perlu dihilangkan. Hal ini dikarenakan nilai factor loadings yang dimiliki oleh semua indikator variabel diatas 0,4. Sehingga dapat disimpulkan bahwa semua indikator dinyatakan valid. Juga dapat dinyatakan bahwa dari semua variabel reliabel dan dapat digunakan untuk pengujian lebih lanjut karena memiliki nilai Cronbach's Alpha diatas 0,7.

\section{Structural Equation Model}

Model SEM terbentuk dari 6 variabel dengan pembahasan masing-masing indikator. Tujuan dari model ini adalah untuk menganalisis hubungan antara masing-masing variabel dan mengetahui apakah semua variabel yang terlibat dalam suatu penelitian telah memenuhi persyaratan kesesuaian atau tidak. Syaratnya, model harus memenuhi kriteria Goodness of Fitness. Hasil pengujian yang dilakukan menunjukkan bahwa model belum dikatakan sesuai karena indeks yang tidak memenuhi persyaratan. Oleh karena itu, dilakukan penyesuaian untuk mendapatkan hasil yang sesuai.

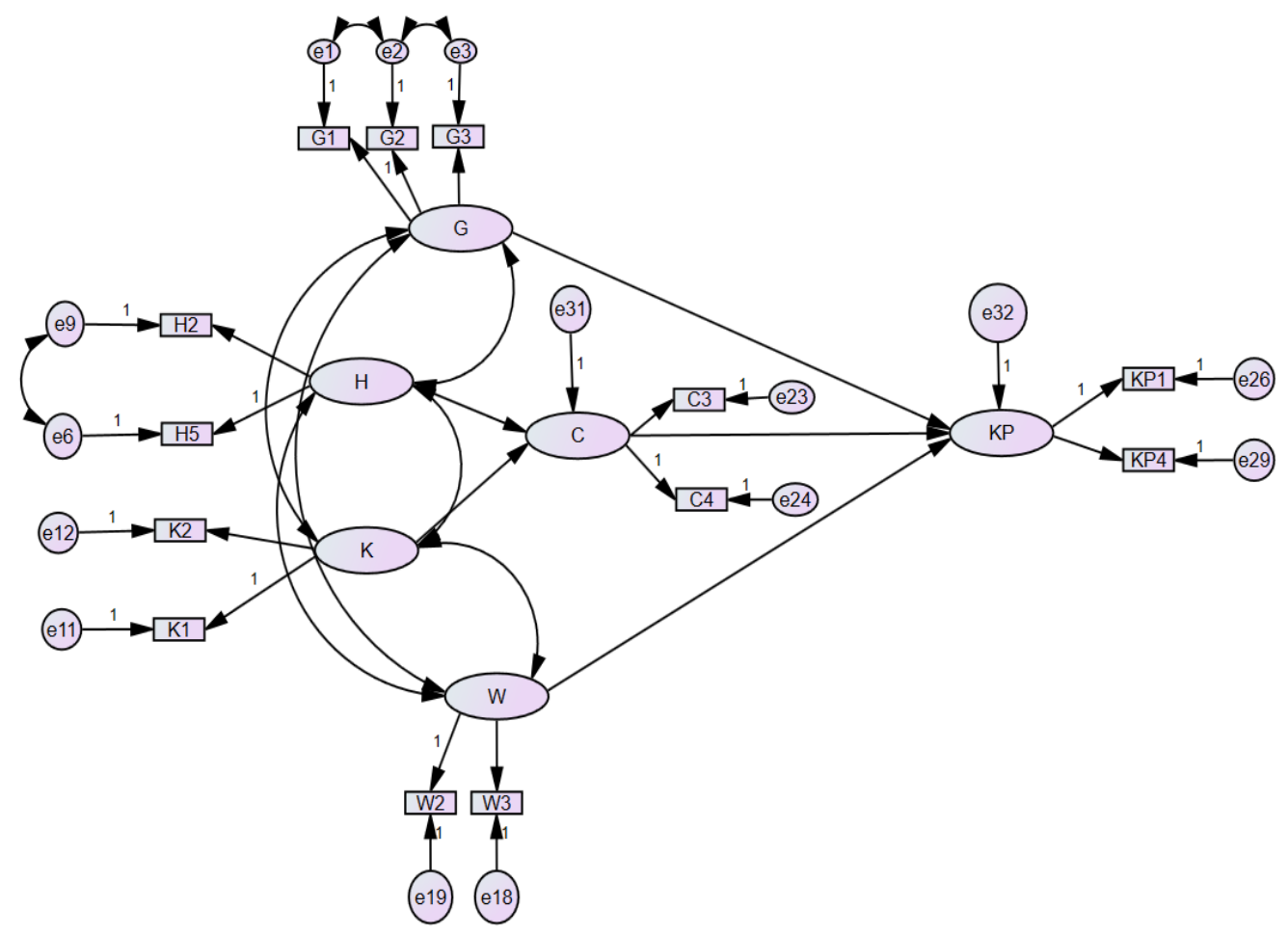

Gambar 2. Model Persamaan Struktural Fit Model 
Jurnal Riset Manajemen Sains Indonesia (JRMSI) | Vol 12, No. 2, 2021 e-ISSN: 2301-8313 http://doi.org/10.21009/JRMSI

Sumber: Data diolah peneliti $(2021$

Tabel 3. Model Persamaan Struktural Fit Model

\begin{tabular}{cccc}
\hline Goodness of Fit Index & Cut-off Value & C.R & Result \\
\hline X2, Chi-Square & Smaller better & 67,315 & Fit \\
Probabilitas & $\geq 0,05$ & 0,063 & Fit \\
GFI & $\geq 0,90$ & 0,959 & Fit \\
RMSEA & $\leq 0,08$ & 0,037 & Fit \\
AGFI & $\geq 0,90$ & 0,927 & Fit \\
TLI & $\geq 0,90$ & 0,976 & Fit \\
NFI & $\geq 0,90$ & 0,940 & Fit
\end{tabular}

Sumber : Data diolah peneliti (2021)

Pada pengujian full SEM model variabel harga memiliki 5 indikator, setelah dimodifikasi ada 2 indikator yang dihilangkan yaitu H1, H3, dan $\mathrm{H} 4$ sehingga model yang diuji memenuhi syarat kesesuaian. Variabel WoM memiliki 5 indikator, setelah dimodifikasi ada 2 indikator yang dihilangkan yaitu W1, W4, dan W5 sehingga model yang diuji memenuhi syarat kesesuaian. Kemudian variabel kualitas produk memiliki 5 indikator, setelah dimodifikasi ada 2 indikator yang dihilangkan yaitu K3, K4, dan K5 sehingga model yang diuji memenuhi syarat kesesuaian. Variabel lifestyle memiliki 5 indikator, setelah dimodifikasi ada 3 indikator yang dihilangkan yaitu G4 dan G5 sehingga model yang diuji memenuhi syarat kesesuaian. Pada variabel citra merek terdapat 5 variabel, untuk mendapatkan model yang fit maka indikator $\mathrm{C} 1$, C2, dan C5 dihilangkan. Sedangkan variabel keputusan pembelian, indikator KP2, KP3, dan KP5 dihilangkan agar memenuhi persyaratan kesesuaian. Dari hasil tersebut dapat dikatakan bahwa model penelitian ini fit.

\section{Uji Hipotesis}

Berikut adalah hasil uji hipotesis:

Table 4. Uji Hipotesis

\begin{tabular}{|c|c|c|c|c|c|c|c|c|}
\hline Hypothesis & $\begin{array}{l}\text { Dependent } \\
\text { Variable }\end{array}$ & & $\begin{array}{l}\text { Independent } \\
\text { Variable }\end{array}$ & Estimate & S.E & C.R & $\mathrm{P}$ & Result \\
\hline H1 & Brand Image & $\leftarrow$ & Price & 0,432 & 0,147 & 2,950 & 0,003 & accepted \\
\hline H2 & Brand Image & $\leftarrow$ & $\begin{array}{l}\text { Product } \\
\text { Quality }\end{array}$ & 0,628 & 0,166 & 3,782 & $* * *$ & accepted \\
\hline
\end{tabular}


Jurnal Riset Manajemen Sains Indonesia (JRMSI) | Vol 12, No. 2, 2021 e-ISSN: 2301-8313 http://doi.org/10.21009/JRMSI

$\begin{array}{rllllllll}\text { H3 } & \text { Purchase } & \leftarrow & \text { Life Style } & 0,961 & 0,594 & 1,617 & 0,106 & \text { rejected } \\ \text { Decision } & & & & & & & \\ \text { H4 } & \begin{array}{l}\text { Purchase } \\ \text { Decision }\end{array} & \leftarrow & \text { Word of } & -1,244 & 0,897 & -1,387 & 0,165 & \text { rejected } \\ & \text { Pouth } & & & & & \\ & \text { Purchase } & \leftarrow & \text { Brand Image } & 1,182 & 0,418 & 2,826 & 0,005 & \text { accepted } \\ & \text { Decision } & & & & & & & \end{array}$

Sumber: Data diolah peneliti (2021

Dari tabel 4 dapat dijelaskan bahwa variabel harga terhadap citra merek memiliki nilai CR sebesar 2,950 (CR > 1,96) dan p-value sebesar 0,003 $(<0,05)$ yang berarti terdapat pengaruh yang signifikan antara variabel harga terhadap citra merek. Dengan demikian hipotesis yang menyatakan bahwa harga akan mempengaruhi citra merek secara positif dan signifikan dapat diterima. Variabel kualitas produk terhadap citra merek memiliki nilai C.R sebesar 3,782 (CR> 1,96) dan p-value sebesar 0,000 $(<0,05)$, yang berarti terdapat pengaruh yang signifikan antara variabel kualitas produk terhadap citra merek. Dengan demikian, hipotesis yang menyatakan bahwa kualitas produk akan mempengaruhi citra merek secara positif dan signifikan dapat diterima. Variabel gaya hidup terhadap keputusan pembelian memiliki nilai C.R sebesar 1,617 $(\mathrm{CR}<1,96)$ dan p-value sebesar 0,106 $(>0,05)$, yang berarti tidak terdapat pengaruh yang signifikan antara variabel gaya hidup terhadap keputusan pembelian. Dengan demikian hipotesis yang menyatakan bahwa gaya hidup berpengaruh positif dan signifikan terhadap keputusan pembelian dapat ditolak.

Variabel word of mouth terhadap keputusan pembelian memiliki nilai CR sebesar $1.387(\mathrm{CR}>1,96)$ dan p-value sebesar $0,165(>0,05)$ yang berarti terdapat pengaruh yang signifikan antara variabel word of mouth terhadap keputusan pembelian. Dengan demikian, hipotesis yang menyatakan bahwa word of mouth mempengaruhi keputusan pembelian secara positif dan signifikan dapat ditolak. Variabel citra merek terhadap keputusan pembelian memiliki nilai CR sebesar 2,826 (CR > 1,96) dan p-value sebesar 0,005 $(<0,05)$ yang berarti terdapat pengaruh yang signifikan antara variabel citra merek terhadap keputusan pembelian. Dengan demikian hipotesis yang menyatakan bahwa citra merek akan mempengaruhi keputusan pembelian secara positif dan signifikan dapat diterima.

\section{Diskusi}

Dengan pengujian yang telah dilakukan maka dapat dianalisa hasil penelitian ini pada pernyataan harga akan mempengaruhi citra merek, disimpulkan bahwa harga mempengaruhi citra merek. dalam hal ini berarti penetapan harga produk dapat mempengaruhi citra perusahaan atau merek 
Jurnal Riset Manajemen Sains Indonesia (JRMSI) | Vol 12, No. 2, 2021 e-ISSN: 2301-8313 http://doi.org/10.21009/JRMSI

tertentu. Dengan demikian, penetapan harga perlu diperhatikan untuk memaksimalkan citra produk yang ingin diciptakan perusahaan. Dalam pernyataan bahwa kualitas produk akan mempengaruhi citra merek, disimpulkan bahwa kualitas produk mempengaruhi citra merek. dalam hal ini berarti kualitas suatu produk juga dapat mempengaruhi citra perusahaan atau merek tertentu. Dengan demikian, menjaga kualitas produk perlu diperhatikan untuk memaksimalkan citra produk yang ingin diciptakan atau dipertahankan oleh perusahaan.

Pada pernyataan bahwa gaya hidup akan mempengaruhi keputusan pembelian, disimpulkan bahwa gaya hidup tidak berpengaruh terhadap keputusan pembelian. Dalam hal ini, gaya hidup masyarakat modern tidak mempengaruhi keputusan pembelian. Hal ini dapat berubah tergantung pada subjek atau responden yang diteliti. Dalam penelitian ini, kualitas produk, harga, dan citra merek lebih berpengaruh daripada gaya hidup terhadap keputusan pembelian. Dalam pernyataan bahwa kualitas produk akan mempengaruhi citra merek, disimpulkan bahwa kualitas produk mempengaruhi citra merek. Pada pernyataan word of mouth akan mempengaruhi keputusan pembelian, disimpulkan bahwa word of mouth tidak berpengaruh terhadap keputusan pembelian. Pada pernyataan bahwa citra merek akan mempengaruhi keputusan pembelian, disimpulkan bahwa citra merek mempengaruhi keputusan pembelian. Dalam hal ini berarti citra suatu merek dapat mempengaruhi keputusan masyarakat untuk membeli produk tertentu. Dengan demikian, membuat citra produk yang baik sangat penting untuk memaksimalkan citra merek dan meningkatkan keputusan pembelian masyarakat. Memperhatikan harga dan menjaga kualitas produk juga dapat membantu membangun citra merek.

\section{KESIMPULAN}

Dengan penelitian yang telah dilakukan dapat disimpulkan bahwa variabel gaya hidup tidak berpengaruh terhadap keputusan pembelian, variabel harga berpengaruh terhadap citra merek, variabel kualitas produk berpengaruh terhadap citra merek, variabel word of mouth tidak berpengaruh terhadap keputusan pembelian, dan variabel citra merek merek berpengaruh terhadap keputusan pembelian.

\section{SARAN}

Dari hasil penelitian yang dilakukan, diketahui bahwa semua variabel yang diteliti dalam penelitian ini dalam kondisi baik. Hal ini terlihat dari hasil kuisioner, dimana responden memiliki kecenderungan untuk memberikan respon yang positif terhadap pernyataan pada semua variabel. Untuk meningkatkan dan menjaga brand image dan pembelian produk pada aplikasi jual beli sayuran online, beberapa hal yang perlu diperhatikan adalah kualitas produk yang ditawarkan pada aplikasi jual beli sayuran online memiliki kualitas yang baik sehingga harus dijaga agar brand image terjaga, harga cukup efektif dan berpengaruh terhadap brand image pada aplikasi jual beli sayur online. Hal ini dapat menjadi 
Jurnal Riset Manajemen Sains Indonesia (JRMSI) | Vol 12, No. 2, 2021 e-ISSN: 2301-8313 http://doi.org/10.21009/JRMSI

acuan bagi perusahaan dalam membentuk brand image yang baik, dan brand image aplikasi jual beli sayuran online memiliki kesan yang baik di masyarakat sehingga harus dipertahankan agar kesan di masyarakat tetap terjaga dan terjaga. diharapkan dapat meningkatkan keputusan pembelian online untuk produk sayuran.

\section{DAFTAR PUSTAKA}

Aji, R. (2016). Digitalisasi, era tantangan media (Analisis Kritis Kesiapan Fakultas Dakwah Dan Komunikasi Menyongsong Era Digital). Islamic Communication Journal, 1(1), $43-$ 54. https://doi.org/10.21580/icj.2016.1.1.1245

Akbar, M. F., \& Anggraeni, F. D. (2017). Teknologi Dalam Pendidikan : Literasi Digital dan Self-Directed Learning pada Mahasiswa Skripsi. Indigenous: Jurnal Ilmiah Psikologi, 2(1), 28-38. https://doi.org/10.23917/indigenous.v1i1.4458

Al-Mahmud, A., \& Rahman, M. K. (2014). A critical review of cunsumers sensitivity to price: managerial and theoritical issues. Journal of International Business and Economics, 2(2), 1-9.

Allshop, D. T., Bassett, B. R., \& Hoskins, J. A. (2007). Word of mouth. Journal of Advertising Research, 47(4), 398-411.

Amanah, D., Hurriyati, R., Gaffar, V., Layla, A. A., \& Harahap, D. A. (2018). Effect of price and product completeness to consumer purchase decision at Tokopedia.com. Global Conference on Business, Management and Entrepreneurship, December 2018, 34-37. https://doi.org/10.5220/0007114300340037

Boksberger, P. ., \& Melsen, L. (2011). Perceived value: a critical examination of definitions, concepts and measures for the service industry. Journal of Service Marketing, 25(3), 229240.

Chu, Y., \& Lee, J. J. (2007). The experiential preferences of the online consumers in different internet shopping lifestyles towards online shopping web sites. Human Computer Interaction, 4553, 3-11.

D’Agostino, R. (2017). Goodness-of-fit-techniques. Routledge.

Djumena, E. (2020). Peluang usaha di tengah pandemi, penjualan sayuran online melonjak. Kompas.Com'. https://money.kompas.com/read/2020/04/25/123300926/peluang-usahadi-tengah-pandemi-penjualan-sayuran-online-melonjak?page=all.

Engel, J. F., \& Blackwell, R. D. (2001). Consumer behavior (9th ed.). Prentice hall.

Esarey, A. (2011). Digital Communication and Political Change in China. International Journal 
Jurnal Riset Manajemen Sains Indonesia (JRMSI) | Vol 12, No. 2, 2021 e-ISSN: 2301-8313 http://doi.org/10.21009/JRMSI

of Communication, 5(0), 22.

Foster, B., \& Johansyah, M. D. (2019). The effect of product quality and price on buying interest with risk as intervening variables (study on Lazada.com site users). International Journal of Innovation, Creativity and Change, 9(12), 66-78. www.ijicc.net

Habibah, U., \& Sumiati. (2016). Pengaruh kualitas produk dan harga terhadap keputusan pembelian produk kosmetik Wardah di Kota Bangkalan Madura. Jurnal Ekonomi, Bisnis \& Entrepreneurship, 1(1), 31-48.

Huber, F., Herrmann, A., \& Henneberg, S. C. (2007). Measuring customer value and satisfaction in services transaction, scale development, validation, and crosscultural comparison. International Journal of Consumer Studies, 31(6), 554-564.

Huges, M. (2007). Buzzmarketing (PT Elex Media Komputindo (ed.)).

Kotler, P. (2005). Manajemen Pemasaran. PT. Index.

Kotler, P., \& Armstrong, G. (2008). Dasar-dasar pemasaran (A. Sindor (ed.); 1st ed.). Prenhalindo.

Kotler, P., \& Keller, K. L. (2016). Marketing management (15th ed.). Prentice hall.

Maney, K. L. (2014). A study on the impact of lifestyle on young Indian consumer purchase decision. Seventeenth AIMS International Conference on Managemen, 1, 902-906.

Park, C. W., Maclinnis, D. J., Priester, J., Eisingerich, A. B., \& Lacobucci, D. (2010). Brand attachment and brand attitiude strength: conceptual and empirical differentiation of two critical brand equity drivers. Journal of Marketing.

Peter, J., \& Olson, P. (2005). Consumer behaviour \& marketing strategy. Mac graw hill Companies Inc.

Pilliang, Y. (2012). Masyarakat Informasi Dan DigitaL: Teknologi Informasi dan Perubahan Sosial. Jurnal Sosioteknologi, 11(27), 143-155.

Saud, M., Ida, R., Abbas, A., Ahmad, R., \& Ashfaq, A. (2020). Media Sosial dan Digitalisasi Partisipasi Politik pada Generasi Muda : Perspektif Indonesia. 8(1), 87-97.

Tambunan, M. R. U. D., \& Anwar, R. (2019). Transformasi Budaya Organisasi Otoritas Perpajakan Indonesia Menghadapi Era Ekonomi Digital. Jurnal Aplikasi Bisnis Dan Manajemen, 5(2), 253-264. https://doi.org/10.17358/jabm.5.2.253

Yasmin, A. (2017). Impact of brand image on consumers' purchase decison. International Journal of Research in Social Sciences, 7(10), 1-18. https://doi.org/2249-2496

Zarei, A., \& Kazemi, A. (2014). The impact of positive word of mouth on store brand purchase 
Jurnal Riset Manajemen Sains Indonesia (JRMSI) | Vol 12, No. 2, 2021 e-ISSN: 2301-8313 http://doi.org/10.21009/JRMSI

intention with mediated effect of store image and perceived risk towards SBs. Journal of Accounting \& Marketing, 3(1), 1-6. https://doi.org/10.4172/2168-9601.1000115 